\title{
Infliximab therapy in pediatric Crohn's disease: a review
}

This article was published in the following Dove Press journal:

Clinical and Experimental Gastroenterology

II June 2010

Number of times this article has been viewed

\section{Kalyan Ray Parashette' \\ Raghavendra Charan \\ Makam $^{2}$ \\ Carmen Cuffari ${ }^{3}$}

'Department of Pediatrics, University of Illinois at Chicago, Chicago, IL, USA; ${ }^{2}$ Department of Internal Medicine, Berkshire Medical Center, Pittsfield, MA, USA; ${ }^{3}$ Division of Pediatric Gastroenterology, The Johns Hopkins Children's Center, Baltimore, MD, USA
Correspondence: Carmen Cuffari The Johns Hopkins School of Medicine, Division of Pediatric Gastroenterology, 600NWolfe St, Brady 320, Baltimore, MD, USA

Email ccuffari@jhmi.edu
Abstract: Anti-tumor necrosis factor alpha (TNF- $\alpha$ ) therapy has re-defined our treatment paradigms in managing patients with Crohn's disease (CD) and ulcerative colitis. Although the ACCENT studies showed proven efficacy in the induction and maintenance of disease remission in adult patients with moderate to severe $\mathrm{CD}$, the pediatric experience was instrumental in bringing forth the notion of "top-down" therapy to improve overall clinical response while reducing the risk of complications resulting from long-standing active disease. Infliximab has proven efficacy in the induction and maintenance of disease remission in children and adolescents with CD. In an open-labeled study of 112 pediatric patients with moderate to severe $\mathrm{CD}, 58 \%$ achieved clinical remission on induction of infliximab $(5 \mathrm{mg} / \mathrm{kg}$ ) therapy. Among those patients who achieved disease remission, 56\% maintained disease remission on maintenance ( $5 \mathrm{mg} / \mathrm{kg}$ every 8 weeks) therapy. Longitudinal follow-up studies have also shown that responsiveness to infliximab therapy also correlates well with reduced rates of hospitalization, and surgery for complication of long-standing active disease, including stricture and fistulae formation. Moreover, these children have also been shown to improve overall growth while maintaining an effective disease remission. The pediatric experience has been instructive in suggesting that the early introduction of anti-TNF- $\alpha$ therapy may perhaps alter the natural history of $\mathrm{CD}$ in children, an observation that has stimulated a great deal of interest among gastroenterologists who care for adult patients with CD.

Keywords: Crohn's disease, infliximab, pediatric

\section{Introduction}

Crohn's disease (CD) and ulcerative colitis are chronic inflammatory intestinal disorders affecting 1.7 million people in North America. ${ }^{1}$ Recent studies have shown an increasing incidence of $\mathrm{CD}$ in children, and an overall prevalence of $10 \%$ to $25 \%$ of all patients with inflammatory bowel disease (IBD). ${ }^{2,3} \mathrm{CD}$ is characterized by patchy transmural inflammation involving any segment of the gastrointestinal tract from the mouth to the anus. Patients will typically show recurrent clinical exacerbations marked by symptoms of abdominal pain, diarrhea, and rectal bleeding, alternating with episodes of quiescent disease. Children often manifest constitutional signs of weight loss, growth failure and pubertal delay that may in part be secondary to extensive proximal small bowel disease of increased severity. Moreover, pediatric CD is often associated with extra intestinal manifestations, including arthritis, episcleritis, uveitis and erythema nodosum. ${ }^{1}$

Although the principal goal of therapy is to induce and maintain an effective disease remission, the intestinal mucosa will often show ongoing inflammation that contributes 
to frequent relapses and less than favorable maintenance of clinical remission. Since CD may progress from intestinal inflammation to strictures and penetrating disease, including fistulas and abscess formation, mucosal healing has become a primary treatment objective. Since delayed puberty and growth failure is seen in $15 \%$ to $40 \%$ of pediatric patients with $\mathrm{CD},{ }^{4}$ achieving normal growth and development also represents an important end-point to therapy. The ultimate goal is to achieve and sustain an effective disease remission that avoids complications associated with long-standing and unremitting disease. To achieve this clinical objective is of paramount importance in order to improve patient quality of life, and avoid psychological complications, including anxiety, and depression. Given the myriad of potential therapies available to treat patients with $\mathrm{CD}$, it has become increasingly important to select those medications with the most favorable benefit risk ratio that will minimize the overall need for corticosteroids (Figure 1).

\section{Non-biological therapy}

Enteral nutrition has proven efficacy in inducing disease remission in children with active $\mathrm{CD},{ }^{5}$ as well as preventing disease relapse in $60 \%$ to $75 \%$ of patients within a year. ${ }^{6,7}$ Although enteral nutrition is effective in inducing disease remission and in reversing micronutrient deficiencies, these treatment formulas are unpalatable and often require nasogastric or gastrostomy tube placement. Typically, adolescent patients are non-adherent to the prolonged implementation of nutritional therapy. They often object to the placement of these feeding tubes or the exclusivity of enteral nutritional therapy during periods of quiescent disease..$^{5-7}$

Thomsen and coworkers showed in a double blind multicenter study of 182 adults with CD that mesalamine was

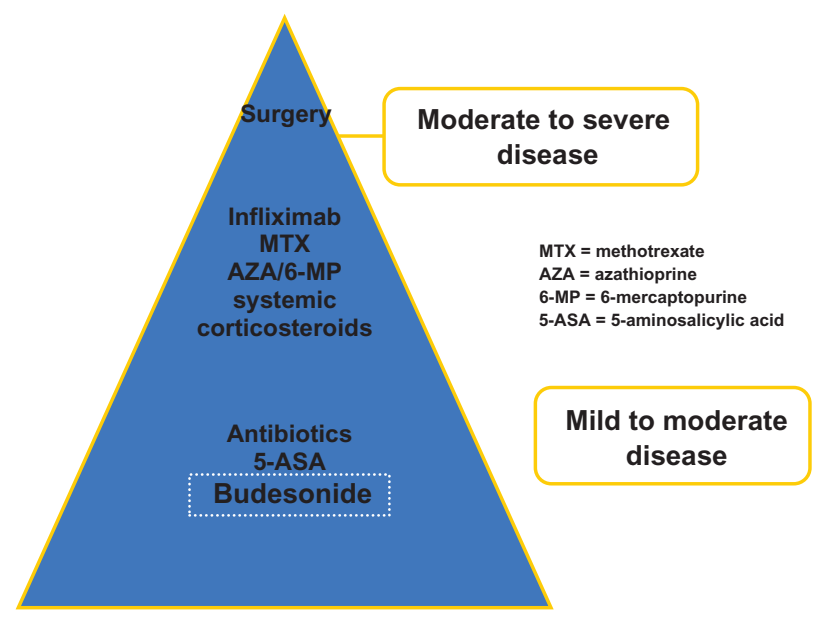

Figure I Crohn's disease practice guideline: pharmacologic pyramid. able to induce remission in $45 \%, 42 \%$ and $36 \%$ of patients with mild to moderate disease at the end of 8 weeks, 12 weeks and 16 weeks, respectively. ${ }^{8}$ However, de Franchis and coworkers showed that once patients achieved disease remission on mesalamine, less than $50 \%$ of patients were able to sustain disease remission after one year of maintenance therapy. ${ }^{9}$

Although studies have shown that corticosteroids are effective in inducing remission in patients with active $\mathrm{CD},{ }^{10}$ not all patients respond favorably. And among those patients that respond to induction corticosteroids, $40 \%$ to $68 \%$ of patients will relapse within a year, while up to $36 \%$ of patients will develop corticosteroid dependency. ${ }^{11-14}$ This observation is also underscored by the detrimental impact of long-term corticosteroid use on patient growth and development.

Immunosuppressant drugs, including methotrexate, azathioprine (AZA, and 6-mercaptopurine (6-MP) are all effective in maintain disease remission in $40 \%$ to $65 \%$ of patients with corticosteroid-dependent moderate to severe CD. ${ }^{15-18}$

\section{Biological therapy}

In comparison, the biological agents used in $\mathrm{CD}$ include: the anti-tumor necrosis factor alpha (TNF- $\alpha$ ) agents infliximab, adalimumab and certolizumab pegol (Figure 2) and anti-adhesion molecule drugs. All of these biological agents have been shown to be effective in children with CD. Herein, our focus will be on the role of infliximab in treating pediatric CD.

\section{TNF- $\alpha$}

Over the last several years, our understanding of the pathogenesis of $\mathrm{CD}$ has improved remarkably with the development of several animal models. Indeed, the proinflammatory cytokine TNF- $\alpha$ is known to play an important role in $\mathrm{CD},{ }^{19}$ and has led to the development of several novel treatment strategies, including infliximab. TNF- $\alpha$ can transmit signals between immune cells leading to inflammation, thrombosis and fibrinolysis. Various stimuli, including bacterial endotoxin, radiation and viral antigens can bring on the release of secretory TNF- $\alpha$ from monocytes, macrophages and T-cell lymphocytes. As a potent proinflammatory cytokine, TNF- $\alpha$ must be firmly regulated; and failure to do so, allows for an unmediated inflammatory response. ${ }^{20}$ In patients with $\mathrm{CD}, \mathrm{TNF}-\alpha$ is highly localized to the intestinal mucosa and lumen. Indeed, high concentrations have been measured in the lamina propria of the bowel of patients with $\mathrm{CD}^{21}$ and increased concentration of TNF has also been found in the stool of children with $\mathrm{CD}^{22}$ At the 

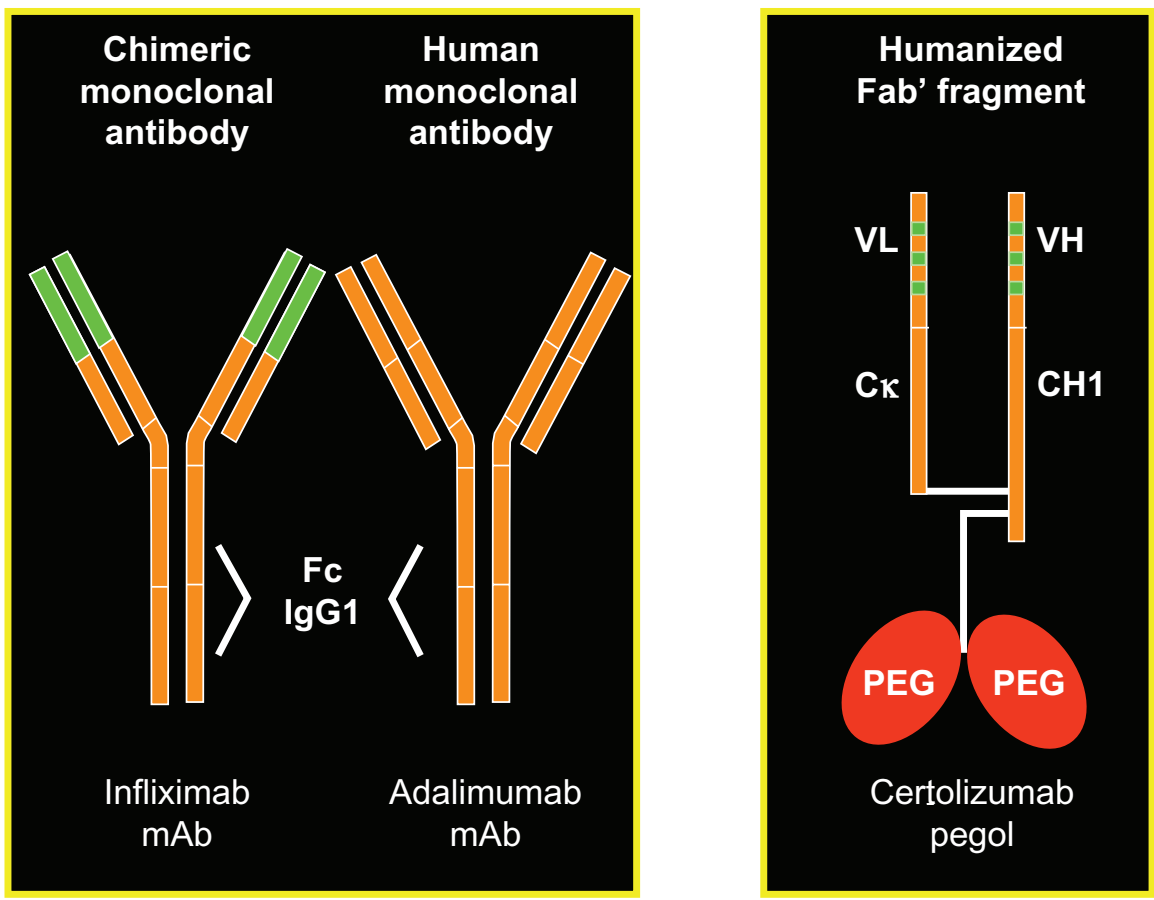

\section{Mouse Human}

Figure 2 Anti-TNF- $\alpha$ structure of 3 biological therapies to treat Crohn's disease.

level of the mucosa, TNF- $\alpha$ recruits circulating inflammatory cells to the intestinal tissue, inducing tissue edema, coagulation activation through thrombin activation and granuloma formation. The migration of neutrophils is further facilitated through the increased expression of adhesion molecules and IL- 8 by endothelial cells. TNF- $\alpha$ is pivotal in the formation of granulomas, one of the histological hallmarks of $\mathrm{CD}$. Through its up-regulation of monocyte chemo-attractant protein-1, monocytes are recruited into the site of gramulomatous inflammation. CD4 T-cell lymphocytes are the probable source for TNF- $\alpha$ production, as well as other cytokines involved in the so-called TH1 response, including interferon- $\alpha$ at the site of granulomas.

\section{Infliximab}

Infliximab is a chimeric IgG-1 monoclonal antibody with a high specificity for TNF- $\alpha$. It induces apoptosis of TNFproducing cells, and promotes antibody dependent and complement dependent cytotoxicity. ${ }^{23-25}$ It has been shown to decrease histologic and endoscopic disease activity and in inducing and maintaining remission in patients with active CD. ACCENT I was a multicenter randomized double-blind international trial studying retreatment and remission maintenance in adult patients with $C D$ treated with infliximab. Patients in this study were divided into 3 groups: patients given a single $5 \mathrm{mg} / \mathrm{kg}$ infusion, patients given $5 \mathrm{mg} / \mathrm{kg}$ every 8 weeks, and patients given $10 \mathrm{mg} / \mathrm{kg}$ every 8 weeks for maintenance of remission. After 54 weeks, the initial clinical response was maintained in only $17 \%$ of patients in the single dose group compared to $43 \%$ of patients maintained on $5 \mathrm{mg} / \mathrm{kg}$ every 8 weeks and $53 \%$ of patients maintained on $10 \mathrm{mg} / \mathrm{kg}$ every 8 weeks. In addition, successful steroid-tapering was seen in only $9 \%$ of patients in the single dose group compared to $28 \%$ in the $5 \mathrm{mg} / \mathrm{kg}$ every 8 weeks group, and $32 \%$ of patients in the $10 \mathrm{mg} / \mathrm{kg}$ every 8 weeks group. ${ }^{26}$

It has been the practice in many institutions, including our own to initiate maintenance anti-TNF- $\alpha$ therapy in patients that have shown clear refractoriness to either longterm 6-MP or AZA therapy. All of the studies, including ACCENT, CHARM and PRECISE have not shown any potential role of combining anti-TNF- $\alpha$ with anti-metabolite therapy. Moreover, the increasing concern of hepatic T-cell lymphoma has led many physicians to consider discontinuing either 6-MP or AZA with the introduction of biological therapy. ${ }^{27}$ Although all anti-TNF $\alpha$ therapies have antigenic properties, those patients on infliximab therapy are most vulnerable. The concurrent use of immunosuppressive therapy has in the past been shown by Rutgeerts and coworkers to maintain a favorable clinical response to maintenance infliximab therapy, presumably due to the prevention of human anti-chimeric antibody (HACA) antibody formation. 
In that study, $75 \%(12 / 16)$ of patients on concurrent $6-\mathrm{MP}$ maintained a favorable clinical response, compared to $50 \%$ (9/18) on no concurrent immunosuppressive therapy. ${ }^{28}$ In the ACCENT 1 study, only $18 \%$ of the patients on neither concurrent prednisone nor immunosuppressive drug therapy developed HACA, compared to just $10 \%$ of patients on concurrent azathioprine or methotrexate therapy. ${ }^{26}$ The therapeutic benefit of concurrent immunosuppressive therapy is generally considered marginal and is felt to not outweigh the associated increased risk of hepatic T-cell lymphomas, a malignancy that is universally lethal in the pediatric patient population. ${ }^{27}$ Moreover, both adalimumab and certolizumab have proven efficacy in salvaging those patients who develop either a partial responsiveness or intolerance to infliximab therapy. ${ }^{28}$ As a result, the purported benefit is not felt to outweigh the increased risk for malignancy.

Other drug safety issues with infliximab include the development of anti-neutrophil antibodies and anti-double stranded DNA in $34 \%$ and $56 \%$ of patients on maintenance infliximab therapy, respectively. Furthermore, the long-term risk in developing systemic lupus is unknown, and may have an increased bearing on the African-American population. Other noteworthy long-term safety issues include the risk of super-infection (32\%) and the risk of tuberculosis. ${ }^{11}$

\section{Adalimumab}

The immunogenicity of infliximab has led to the development of other less immunogenic TNF inhibitory agents, including adalimumab and certolizumab. Adalimumab (fully human anti-TNF) has recently received approval for the treatment of active CD. Several studies have shown adalimimab to be superior to placebo for inducing and maintaining remission. It has also been shown to spare corticosteroids and salvage those patients with CD recalcitrant to infliximab therapy with an excellent safety profile. Unlike infliximab, adalimumab is prescribed as a subcutaneous injection every 2 weeks as a maintenance therapy. ${ }^{28,29}$

\section{Infliximab use in children}

Studies evaluating the safety and efficacy of infliximab in children were first reported in several non-randomized studies. ${ }^{30-34}$ These initial studies showed that the response and remission rates (both partial and complete) were far superior compared to conventional therapy. Interestingly, its efficacy in children appeared to be higher than in adult. ${ }^{31,32}$

In a multicenter, open-label, dose-blinded trial $(n=21)$, Baldassano and coworkers demonstrated the efficacy and safety of a single infusion of infliximab in the treatment of pediatric CD. During the 12-week duration of the study, $100 \%$ achieved a clinical response and $48 \%$ achieved clinical remission, with significant improvements in the pediatric $C D$ activity index (PCDAI), modified CDAI, erythrocyte sedimentation rate, and other outcome variables of interest. There were no infusion reactions in any of the patients and it was suggested that infliximab may be safe and effective as shortterm therapy of medically refractory moderate to severe CD. ${ }^{35}$ A prospective study published by Cezard and coworkers also explored the efficacy and toxicity of infliximab in children with severe $C D$. Twenty-one children (median age 15 , range 13 to 17 ) were treated with infliximab with an induction sequence of $5 \mathrm{mg} / \mathrm{kg}$ at 0,15 , and 45 days. Nineteen children were in complete remission (defined as Harvey-Bradshaw index $(\mathrm{HBI})<4$ ) on day 45. 14/21 patients had stopped taking steroids at 3 months, and all had stopped parenteral nutrition. All perianal fistulas $(n=12)$ were also closed by day 90 and the drug appeared to be well tolerated. ${ }^{36}$

Much evidence at present comes from retrospective analysis of children treated with infliximab, often as a rescue medication. In a retrospective study in children and adolescents with either corticosteroid dependent or resistant $\mathrm{CD}$, patients were randomized to receive 1 to 3 infusions of infliximab ( $5 \mathrm{mg} / \mathrm{kg} / \mathrm{dose}$ ) over a 12 -week period. The mean daily prednisone dosages decreased significantly in all the patients $(P<0.01)$ studied. A significant initial improvement (as assessed by a significant decline in PCDAI value) was noted in all subjects $(P<0.0001)$. Interestingly, over the subsequent 8 -week period, 8 of 19 treated subjects had worsening of symptoms. ${ }^{37}$ Lamireau and coworkers described yet another retrospective study in 88 children and adolescents (median age: 14 , range: 3.3 to 17.9 ) treated with infliximab for active disease $(66 \%)$ and/or fistulas $(42 \%)$ that were refractory to corticosteroids $(70 \%)$, and/or other immunosuppressive (82\%) agents, and/or parenteral nutrition (20\%). Patients received a median of 4 ( 1 to 17) infusions of $5 \mathrm{mg} / \mathrm{kg}$ of infliximab during a median time period of 4 months ( 1 to 17 months). From day 0 to day 90, the Harvey-Bradshaw score decreased from 7.5 to $2.8(P<0.001)$, with a significant decrease in both $C$-reactive protein and $\operatorname{ESR}(P<0.001)$. At day 90 after the first infusion of infliximab, $49 \%$ of patients had symptom improvement, $29 \%$ were in remission; $53 \%$ of patients could be weaned off of corticosteroids and $92 \%$ off of parenteral nutrition. ${ }^{38}$ The authors in both these studies concluded that treatment with infliximab was well tolerated and effective in most children and adolescents with $\mathrm{CD}$ refractory to conventional immunosuppressive therapy. No serious events were noted in any of these studies. 
The Food and Drug Administration (FDA) approval for the use of infliximab therapy in pediatric $\mathrm{CD}$ was based on the results of the much publicized REACH clinical study, a randomized, multicenter, open-label study to evaluate the safety and efficacy of anti-TNF- $\alpha$ antibody in pediatric subjects with moderate to severe CD. A total of 112 pediatric patients (ages 6 to 17 years) with moderate to severe $\mathrm{CD}$ who took part in this study received infliximab at $5 \mathrm{mg} / \mathrm{kg}$ at week 0,2 and 6 . Patients who showed symptom improvement, or response, were then randomized to 2 groups and received infliximab every 8 or 12 weeks for almost 1 year. A concurrent immunomodulator was also required. At week $10,88 \%$ patients showed response (defined as decrease from baseline in the PCDAI score $\geq 15$ points; total score $\leq 30$ ) and $58 \%$ patients achieved clinical remission (defined as PCDAI score $\leq 10$ points). At week 54, 63\% and 56\% patients receiving infliximab every 8 weeks were in clinical response and clinical remission, respectively, compared with $33 \%$ and $23 \%$ patients receiving treatment every 12 weeks ( $P=0.002$ and $P<0.001$, respectively). The data from this important prospective trial thus suggested that infliximab is not only highly effective in inducing clinical response and remission but also in maintenance of remission, more so with an 8 -week dosing compared with every 12 -week dosing. ${ }^{39}$ The same research consortium also found infliximab to be an effective therapy in children with perianal disease, including patients with perianal fistula, ${ }^{40}$ and in prolonging the withdrawal of corticosteroids over a 3-year follow-up period. ${ }^{41}$ Similar observations have also been made in an European study in children with CD. In that study, children on an on-demand treatment schedule were more-likely to experience a relapse $(92 \%)$ when compared to patients on 2-month infusion schedule $(23 \%){ }^{42}$

\section{Immunogenicity}

HACA is the common side effect of infliximab infusion. The antibody is as a result of murine component of chimeric infliximab. However, adalimumab a fully human anti-TNF- $\alpha$ drug also has similar side-effects. In the REACH study, $2.9 \%$ (3 patients) developed HACA when compared to $35 \%$ on other trials. ${ }^{39,43-45}$ This could be explained by patients in the REACH study receiving concurrent immunosuppressive medication. Seventy-seven percent of patients in the REACH had inconclusive HACA results. HACA causes infusion reactions (acute and delayed), shortened response and also loss of response. Risk factors for development of HACA are single and episodic infusion, female gender, long gap between first and second infusion, and previous infusion reaction. Studies suggest that it can me minimized by giving maintained therapy, a concomitant immunosuppressive agent, and corticosteroid..$^{44,45}$

Acute infusion reaction occurs in $11 \%$ to $8 \%$ patients and at $2.5 \%$ to $5.3 \%$ per infusion depending on the dosing method and concomitant treatment. ${ }^{39,46-48}$ Patients develop pruritus, chest pain, nausea, headache, and flushing within 24 hours. Antihistamines and/or corticosteroids do not prevent the infusion reaction. However, infusion reaction can be controlled by slow infusion, along with administration of antihistamine and corticosteroids. It is our general practice to pre-medicate those patients susceptible to infliximab-induced infusion reactions with hydrocortisone therapy. ${ }^{48}$

Delayed infusion reaction is very rare $(0.7 \%$ to $3 \%)$. Patients presents after 4 to 9 days with back pain, myalgia, arthralgia, and skin rash. ${ }^{46,47}$ It is seen after the second or third infusion dose and usually responds to corticosteroid therapy.

Infliximab therapies often induce formation of anti nuclear antibody and anti double standard antibody. ${ }^{49}$ However these antibodies are not of any clinical significance as studies suggest that no pediatric patients have developed drug-induced systemic lupus or organ damage.

\section{Infections}

Infliximab causes decreased levels of polymorph nuclear cells and T-cell lymphocytes specifically at mucosal site. This results in increased risk of infectious with bacteria, virus and fungi. Active infection is a contraindication for infliximab use. Also, live vaccines are contraindicated as there is an increase risk of serious infection. Every patient has to undergo a screening test for tuberculosis, as multiple studies suggest reactivation of latent tuberculosis. ${ }^{50,51}$

The risk of infection is $3.8 \%$ to $8 \%$ and the upper respiratory tract is commonly affected. ${ }^{26,52}$ In the REACH study, the incidence rate of upper respiratory tract infection was $35.8 \%$ and $32.0 \%$ in patients receiving infliximab every 8 weeks and every 12 weeks, respectively. ${ }^{39}$ Overall infection rate was high $(73.6 \%)$ among the first group patients than the later group (38.0\%). But serious infection occurred at the same rate in both the groups $(5.7 \%$ to $8 \%)$. In a study of adult patients with $\mathrm{CD}$, Colombel and coworkers treated 500 patients with infliximab, $41(8.2 \%)$ of whom developed infection. Among these 41 patients, 15 had serious infection (2 fatal sepsis, 8 pneumonia, 1 severe viral gastroenteritis, 2 abdominal abscess, 1 arm cellulitis, 1 histoplasmosis). ${ }^{53}$ Other studies also suggest the occurrence of Listeria monocytogenes meningitis, cutaneous Tinea, shingles, and 
herpes zoster. ${ }^{45,54}$ One report also suggests reactivation of hepatitis B in 3 patients diagnosed with chronic hepatitis B on treatment with infliximab. ${ }^{55}$

\section{Malignancy}

In a prospective study of 20 patients, 28\% developed reactivation of Epstein-Barr virus (EBV). However, EBV PCR level returned to normal after 6 months of discontinuing infliximab. ${ }^{56}$ In a study of 6290 adult patients on maintenance infliximab therapy, there was no increased risk of malignancy in the infliximab group compared to patients on conventional therapy. ${ }^{57}$ In a multi-center matched-pair trial, the incidence rate of malignancy was $2.2 \%$ (9 patients) in the $\mathrm{CD}$ group and $1.7 \%$ ( 7 patients) in the non-CD group after a followup of 4.5 years. ${ }^{58}$ Meena and coworkers first reported a case of hepatosplenic T-cell lymphoma in a 17-year-old female $\mathrm{CD}$ patient treated with infliximab and 6-MP. ${ }^{27}$ Nine more cases of hepatic T-cell lymphoma have been reported in IBD patients treated with infliximab and 6-MP/AZA. ${ }^{59}$ However there is no case report of an IBD patient developing hepatic T-cell lymphoma on infliximab alone.

\section{Summary}

The arsenal of biological therapies is increasing. A large multi-centered pediatric study is now investigating the use of adalimumab in children with CD. Furthermore, the FDA approval of certolizumab, a novel pegylated anti-TNF therapy, is expected soon. The pediatrician will soon be faced with the dilemma of which medications to use, in either the more traditional step-up or top-down approach. Indeed, there is a growing tendency to consider biological drugs in lieu of more traditional therapies, as discussed above. While genotypephenotype correlations may allow clinicians to predict certain more aggressive forms of $\mathrm{CD}$, future studies are still needed to provide an evidenced-based approach to drug therapy.

\section{Disclosures}

Dr Cuffari is a consultant for, and receives research support from, UCB, the manufacturer of certolizumab.

\section{References}

1. Cuffari C. Inflammatory bowel disease in children: A pediatrician's perspective. Minerva Pediatr. 2006;58(2):139-157.

2. Kugathasan S, Judd RH, Hoffmann RG, et al. Epidemiologic and clinical characteristics of children with newly diagnosed inflammatory bowel disease in wisconsin: A statewide population-based study. $J$ Pediatr. 2003;143(4):525-531.

3. Hildebrand H, Finkel Y, Grahnquist L, et al. Changing pattern of paediatric inflammatory bowel disease in northern stockholm 1990-2001. Gut. 2003;52(10):1432-1434.

4. Griffiths AM, Nguyen P, Smith C, et al. Growth and clinical course of children with crohn's disease. Gut. 1993;34(7):939-943.
5. Hiwatashi N. Enteral nutrition for crohn's disease in Japan. Dis Colon Rectum. 1997;40(10 Suppl):S48-S53.

6. Griffiths AM, Ohlsson A, Sherman PM, et al. Meta-analysis of enteral nutrition as a primary treatment of active crohn's disease. Gastroenterology. 1995;108(4):1056-1067.

7. Gonzalez-Huix F, de Leon R, Fernandez-Banares F, et al. Polymeric enteral diets as primary treatment of active crohn's disease: A prospective steroid controlled trial. Gut. 1993;34(6):778-782.

8. Thomsen OO, Cortot A, Jewell D, et al. A comparison of budesonide and mesalamine for active crohn's disease. international budesonidemesalamine study group. $N$ Engl J Med. 1998;339(6):370-374.

9. de Franchis R, Omodei P, Ranzi T, et al. Controlled trial of oral 5-aminosalicylic acid for the prevention of early relapse in crohn's disease. Aliment Pharmacol Ther. 1997;11(5):845-852.

10. Levine A, Weizman Z, Broide E, et al. A comparison of budesonide and prednisone for the treatment of active pediatric crohn disease. J Pediatr Gastroenterol Nutr. 2003;36(2):248-252.

11. Munkholm P, Langholz E, Davidsen M, et al. Frequency of glucocorticoid resistance and dependency in crohn's disease. Gut. 1994;35(3): $360-362$.

12. Greenberg GR, Feagan BG, Martin F, et al. Oral budesonide for active crohn's disease. canadian inflammatory bowel disease study group. N Engl J Med. 1994;331(13):836-841.

13. Rutgeerts P, Lofberg R, Malchow $\mathrm{H}$, et al. A comparison of budesonide with prednisolone for active crohn's disease. $N$ Engl J Med. 1994; 331(13):842-845.

14. Campieri M, Ferguson A, Doe W, et al. Oral budesonide is as effective as oral prednisolone in active crohn's disease. the global budesonide study group. Gut. 1997;41(2):209-214.

15. Candy S, Wright J, Gerber M, et al. A controlled double blind study of azathioprine in the management of crohn's disease. Gut. 1995;37(5): 674-678.

16. Markowitz J, Grancher K, Kohn N, et al. A multicenter trial of 6-mercaptopurine and prednisone in children with newly diagnosed crohn's disease. Gastroenterology. 2000;119(4):895-902.

17. Feagan BG, Rochon J, Fedorak RN, et al. Methotrexate for the treatment of crohn's disease. the north american crohn's study group investigators. N Engl J Med. 1995;332(5):292-297.

18. Feagan BG, Fedorak RN, Irvine EJ, et al. A comparison of methotrexate with placebo for the maintenance of remission in crohn's disease. north american crohn's study group investigators. N Engl J Med. 2000; 342(22):1627-1632.

19. Bell SJ, Kamm MA. Review article: The clinical role of anti-TNFalpha antibody treatment in crohn's disease. Aliment Pharmacol Ther. 2000; 14(5):501-514.

20. Reinecker HC, Steffen M, Witthoeft T, et al. Enhanced secretion of tumour necrosis factor-alpha, IL-6, and IL-1 beta by isolated lamina propria mononuclear cells from patients with ulcerative colitis and crohn's disease. Clin Exp Immunol. 1993;94(1):174-181.

21. Nicholls S, Stephens S, Braegger CP, et al. Cytokines in stools of children with inflammatory bowel disease or infective diarrhoea. J Clin Pathol. 1993;46(8):757-760.

22. Cornillie F, Shealy D, D'Haens G, et al. Infliximab induces potent anti-inflammatory and local immunomodulatory activity but no systemic immune suppression in patients with crohn's disease. Aliment Pharmacol Ther. 2001;15(4):463-473.

23. Lugering A, Schmidt M, Lugering N, et al. Infliximab induces apoptosis in monocytes from patients with chronic active crohn's disease by using a caspase-dependent pathway. Gastroenterology. 2001;121(5): $1145-1157$.

24. ten Hove T, van Montfrans C, Peppelenbosch MP, et al. Infliximab treatment induces apoptosis of lamina propria T lymphocytes in crohn's disease. Gut. 2002;50(2):206-211.

25. Scallon BJ, Moore MA, Trinh H, et al. Chimeric anti-TNF-alpha monoclonal antibody cA2 binds recombinant transmembrane TNFalpha and activates immune effector functions. Cytokine. 1995;7(3): 251-259. 
26. Hanauer SB, Feagan BG, Lichtenstein GR, et al. Maintenance infliximab for Crohn's disease: the ACCENT I randomized trial. Lancet. 2002; 359:1541-1549.

27. Thayu M, Markowitz JE, Mamula P, et al. Hepatosplenic T-cell lymphoma in an adolescent patient after immunomodulator and biologic therapy for crohn disease. J Pediatr Gastroenterol Nutr. 2005;40(2): 220-222.

28. Colombel JF, Sandborn WJ, Rutgeerts P, et al. Adalimumab for maintenance of clinical response and remission in patients with Crohn's disease: the CHARM study. Gastroenterology. 2007;132:52-55.

29. Rutgeerts P, D'Haens G, Targan S, et al. Efficacy and safety of retreatment with anti-tumor necrosis factor antibody to maintain remission in Crohn's disease. Gastroenterology. 1999;117:761-769.

30. Kugathasan S, Werlin SL, Martinez A, et al. Prolonged duration of response to infliximab in early but not late pediatric crohn's disease. Am J Gastroenterol. 2000;95(11):3189-3194.

31. Lionetti P, Bronzini F, Salvestrini C, et al. Response to infliximab is related to disease duration in paediatric crohn's disease. Aliment Pharmacol Ther. 2003;18(4):425-431.

32. Borrelli $\mathrm{O}$, Bascietto $\mathrm{C}$, Viola F, et al. Infliximab heals intestinal inflammatory lesions and restores growth in children with crohn's disease. Dig Liver Dis. 2004;36(5):342-347.

33. Veres G, Baldassano RN, Mamula P. Infliximab therapy in children and adolescents with inflammatory bowel disease. Drugs. 2007;67(12): 1703-1723.

34. de Ridder L, Benninga MA, Taminiau JA, et al. Infliximab use in children and adolescents with inflammatory bowel disease. J Pediatr Gastroenterol Nutr. 2007;45(1):3-14.

35. Baldassano R, Braegger CP, Escher JC, et al. Infliximab (REMICADE) therapy in the treatment of pediatric crohn's disease. Am J Gastroenterol. 2003;98(4):833-838.

36. Cezard JP, Nouaili N, Talbotec C, et al. A prospective study of the efficacy and tolerance of a chimeric antibody to tumor necrosis factors (remicade) in severe pediatric crohn disease. J Pediatr Gastroenterol Nutr. 2003;36(5):632-636.

37. Hyams JS, Markowitz J, Wyllie R. Use of infliximab in the treatment of crohn's disease in children and adolescents. J Pediatr. 2000;137(2): 192-196.

38. Lamireau T, Cezard JP, Dabadie A, et al. Efficacy and tolerance of infliximab in children and adolescents with crohn's disease. Inflamm Bowel Dis. 2004;10(6):745-750.

39. Hyams J, Crandall W, Kugathasan S, et al. Induction and maintenance infliximab therapy for the treatment of moderate-to-severe Crohn's disease in children. Gastroenterology. 2007;132(3):863-873.

40. Crandall W, Hyams J, Kugathasan S, et al. Infliximab therapy in children with concurrent perianal Crohn disease: observation from REACH. J Pediatr Gastroenterol Nutr. 2009;49:183-190.

41. Ruemmele FM, Lachaux A, Cezard JP, et al. Efficacy of infliximab in pediatric Crohn's disease: a randomized multi-center open-label trial comparing schedule to on demand maintenance therapy. Inflamm Bowel Dis. 2009;15:388-394.

42. Hyams JS, Lerer T, Griffiths A, et al. Long-term outcome of maintenance infliximab therapy in children with Crohn's disease. Inflamm Bowel Dis. 2009; 15:816-822.
43. Candon S, Mosca A, Ruemmele F, et al. Clinical and biological consequences of immunization to infliximab in pediatric crohn's disease. Clin Immunol. 2006;118(1):11-19.

44. Miele E, Markowitz JE, Mamula P, et al. Human antichimeric antibody in children and young adults with inflammatory bowel disease receiving infliximab. J Pediatr Gastroenterol Nutr. 2004;38(5):502-508.

45. Baert F, Noman M, Vermeire S, et al. Influence of immunogenicity on the long-term efficacy of infliximab in crohn's disease. $N$ Engl J Med. 2003;348(7):601-608.

46. Friesen CA, Calabro C, Christenson K, et al. Safety of infliximab treatment in pediatric patients with inflammatory bowel disease. J Pediatr Gastroenterol Nutr. 2004;39(3):265-269.

47. Crandall WV, Mackner LM. Infusion reactions to infliximab in children and adolescents: Frequency, outcome and a predictive model. Aliment Pharmacol Ther. 2003;17(1):75-84.

48. Jacobstein DA, Markowitz JE, Kirschner BS, et al. Premedication and infusion reactions with infliximab: Results from a pediatric inflammatory bowel disease consortium. Inflamm Bowel Dis. 2005;11(5):442-446.

49. Vermeire S, Noman M, Van Assche G, et al. Autoimmunity associated with anti-tumor necrosis factor alpha treatment in crohn's disease: A prospective cohort study. Gastroenterology. 2003;125(1):32-39.

50. Myers A, Clark J, Foster H. Tuberculosis and treatment with infliximab. N Engl J Med. 2002;346(8):623-626.

51. Keane J, Gershon S, Wise RP, et al. Tuberculosis associated with infliximab, a tumor necrosis factor alpha-neutralizing agent. $N$ Engl $J$ Med. 2001;345(15):1098-1104.

52. Veres G, Baldassano RN, Mamula P. Infliximab therapy in children and adolescents with inflammatory bowel disease. Drugs. 2007;67(12): 1703-1723.

53. Colombel JF, Loftus EV Jr, Tremaine WJ, et al. The safety profile of infliximab in patients with crohn's disease: The mayo clinic experience in 500 patients. Gastroenterology. 2004;126(1):19-31.

54. Kamath BM, Mamula P, Baldassano RN, et al. Listeria meningitis after treatment with infliximab. J Pediatr Gastroenterol Nutr. 2002; 34(4):410-412.

55. Esteve M, Saro C, Gonzalez-Huix F, et al. Chronic hepatitis B reactivation following infliximab therapy in crohn's disease patients: Need for primary prophylaxis. Gut. 2004;53(9):1363-1365.

56. Cezard JP, Nouaili N, Talbotec C, et al. A prospective study of the efficacy and tolerance of a chimeric antibody to tumor necrosis factors (remicade) in severe pediatric crohn disease. J Pediatr Gastroenterol Nutr. 2003;36(5):632-636.

57. Lichtenstein GR, Feagan BG, Cohen RD, et al. Serious infections and mortality in association with therapies for crohn's disease: TREAT registry. Clin Gastroenterol Hepatol. 2006;4(5):621-630.

58. Biancone L, Orlando A, Kohn A, et al. Infliximab and newly diagnosed neoplasia in crohn's disease: A multicentre matched pair study. Gut. 2006;55(2):228-233.

59. Mackey AC, Green L, Liang LC, et al. Hepatosplenic T cell lymphoma associated with infliximab use in young patients treated for inflammatory bowel disease. J Pediatr Gastroenterol Nutr. 2007;44(2):265-267.
Clinical and Experimental Gastroenterology

\section{Publish your work in this journal}

Clinical and Experimental Gastroenterology is an international, peerreviewed, open access journal, publishing all aspects of gastroenterology in the clinic and laboratory, including: Pathology, pathophysiology of gastrointestinal disease; Investigation and treatment of gastointestinal disease; Pharmacology of drugs used in the alimentary tract;

\section{Dovepress}

Immunology/genetics/genomics related to gastrointestinal disease. This journal is indexed on CAS. The manuscript management system is completely online and includes a very quick and fair peer-review system. Visit http://www.dovepress.com/testimonials.php to read real quotes from published authors. 